\title{
The Disciplinary Issues in Malay Figurative Language and Its Similarities with Majaz Concept of the Arabic Rhetoric
}

\author{
Abu Hassan Abdul, PhD \\ Associate Professor at Department of Malay Language and Literature \\ Sultan Idris Education University (UPSI), Malaysia \\ ahassan@fbk.upsi.edu.my \\ Wahibah Twahir \\ H.Tahir, PhD \\ Senior Lecturer at Department of Islamic Studies \\ Sultan Idris Education University (UPSI), Malaysia \\ wahibah@fsk.upsi.edu.my
}

\begin{abstract}
The article discusses main issues in Malay figurative language and its potential in developing into a new discipline. One of the main issues, the concept of Malay rhetoric knowledge or discipline is not systematically and accurately organized for hundred years. There is a major misunderstanding in the knowledge and overlapping concepts in terms of stylistic, semiotic, esthetic, discourse and poetic. The Malay rhetoric knowledge seems small and lifeless in modern Malay linguistics and literature study because it lacks innovation which enables in enriching its concepts and structures within the perspective of Malay world and its sociocultural view. This research attempts to enlighten the figurative language values from rhetorical view and to figure out the similarities between Malay figurative languages with the concept of majaz in Arabic rhetoric. This uniqueness points out the potential of figurative language to be strengthened and combined with other branches of knowledge in Malay rhetoric arts. The success of strengthening the figurative language can act as a starting point to a more holistic innovation of the discipline towards the great unity of Malay rhetoric knowledge, which is influential and stronger in carrying meaning in understanding Malay thinking pattern and their socio cultural in communicating through multiple language genres.
\end{abstract}

Keywords: rhetoric, Arabic rhetoric, Malay figurative language, majaz.

\section{Introduction}

Malay rhetoric knowledge has not been discussed seriously for a very long time. In many seminars related to Malay Language and Literature in Asian region, researchers do not pay attention to Malay rhetoric issues as if it does not exist in Malay epistemology. Almost no effort has been made to uphold this knowledge and to make sure that Malay rhetoric can be learned systematically, and to benefit from it throughout the World as well as Arabic rhetoric knowledge. This article focuses on one form of Malay rhetoric knowledge, namely the figurative language and its similarities with the art of majaz in Arabic rhetoric, with the hope that it will be a starting point to a more research and discussion to put this discipline in a higher position in par with other linguistic disciplines, and to raise the scope of Malay language discipline in the world. This Malay knowledge treasure needed to be studied and strengthened because of its potentials to become one of the main pillars in Malay study in the future. 


\section{Issue and Problems}

Malay scholar, U.U. Hamedy (1998, p 20) mentions that Malays tend to think in symbolic and figurative manner as they express their thinking using metaphoric concepts. This is strongly related to the shyness of Malays as well as their emotional traits or nature, which is to avoid dispute. The Malay language is a reflection of this a behavior and moral. This is the reason for the poetic richness and beautiful saying among Malays. It is known as proverb, imagery, simile and pantun (Malay poetic form). This thinking pattern is similar to the Arabic rhetoric concept as interpreted in tasybih, kinayah, isti'arah and majaz. But the element of majaz has more influences upon Malay thinking and speaking arts since classical time until today.

Majaz is a word borrowed from the Arabic rhetoric knowledge, which can be defined as an art that prioritize the beauty of language in many forms. Its language usage does not restrict to linguistic aspect only but also in other characters in a systematic and arranged meaning, esthetically and logical. (Abdul Kadir Hussain, 1997, p 60). Meanwhile balaghah has always been translated as rhetoric in Malay, although it has broader meaning than rhetorical knowledge such as poetic and stylistic.

Before the spread of western rhetoric in South East Asia, Malay scholars were influenced by Arabic balaghah pattern which can be seen in writing of Jawi books as reflected in many Jawi texts that are similiar to Arabic language style. For example Tuhfat Al-Nafis, Aqa'id al-Nasafi or Bustanul Katibin. Although Arabic balaghah strongly influenced the writing of Jawi books in that period, it did not encourage South East Asia scholars to write or compile a specific book in Malay rhetoric knowledge based on their wisdom on Arabic rhetoric knowledge. Ironically, as rhetoric knowledge has been developing for hundreds years in the Middle East, and was known at West as rhetoric, its development at Malay world really in disappointing situation. Balaghah only dominated the Arabic language study at the pondok, pesantren and religious schools but did not influence the language system and Malay literature in South East Asia.

After the western imperialism period, history shows that most of Malay language disciplines were influenced by linguistic theory and Western literature, whether from modern trend or post-modern. There are no serious efforts to absorb Arabic rhetoric concepts into Malay language system in order to strengthen Malay language abilities and make it more dynamic. The Malay rhetoric's potential and prospect has only been researched in minor scale to widen the Malay study field. The comprehension, scope and knowledge definition in this discipline is still in its old structure and lacking in serious effort to rejuvenate this discipline.

This problem which is over-dependent on the concept, theory, knowledge classification and western rhetoric dichotomy, and the Malay linguistic scholars' weakness in mastering advance Arabic language results in small number of cross-field research related to the connection between Arabic rhetoric and Malay rhetoric. Previous Malay language experts such as $Z^{2} a^{\prime} a^{1}$ and Raja Ali Haji were very fluent in the advanced Arabic language and these have been reflected in their books, for example, Bustan al-Arifin and Kitab Pengetahuan Bahasa which discussed about Malay language and Arabic language approach and issues.

This weakness results in great impact in the context of rhetoric definition in modern Malay study which only discusses secularisms and understanding of old discussions on alliteration, dissonance, hyperbole, personification, allusion and anadiplosis and others. The truth is that the vocabulary borrowed from the Greek are not recognized in the Malay philosophy and rhetoric. This is because the over-dependent on rhetoric epistemology from other civilization makes the esthetically rich Malay rhetoric seemed small and lifeless in contemporary Malay study.

Historical research proved that Malay oral literature strength which was rich with rhetorical characteristic was underestimated by Winstedt, a person who researched many classical Malay language and literature. Winstedt and Wilkinson's narrow opinions and other European researchers towards this oral literature was influenced by western opinion in imperialism period that only recognize written literature of Malay literature as canon thus did not recognize oral literature as an important Malay civilization heritage although the civilization and literature history in Malay World were really different from the knowledge and development in Europe. In other words, the wide and esthetic Malay literature tradition could not

1 The first Malay scholar who compiled and organized Malay grammar. 
be comprehended by European researchers in the imperialism period. The problem as recognized by Arnd Graf (2002, $p$ xvi-xvii) in one of his writings:

...In Malay world, verbal tradition is a sacrifice to narrow minded as many Malay tradition aspect gain no appreciation and recognition. Most of the important Malay tradition genres are speech, correspondence, tongue fight (debate) and the isolated Malay language and literature during imperialism period are idioms, language style and others.

This problem continued until Za'ba who wrote Ilmu Mengarang Melayu (1934) elaborated Malay composition concept. Za'ba presents sentences, sayings and phrase that contain rhetoric characteristic. Researchers prefer to evaluate this book from composition side, semantic and pragmatic, although Za'ba opinions from the book carried wider ideas of knowledge from that issue. Only in 1995, Hashim Awang (1995, p 487) and Asmah (2014, p 157) acknowledged Za'ba book Ilmu Mengarang Melayu as a reflection of Malay rhetoric concept.

Za'ba uses "kiasan/figurative", a term in a long list of figurative language as flowering figurative, sweetener figurative, jumping figurative, migrated figurative, poetic figurative, distracted figurative, other than express the language diversity, which are satire language, blame language, inverted language, hyperbole language, and more (Za'ba, 2002, p 206). Although the rhetoric entry has existed in English dictionary, but he did not use this terms in his books. In contrast, he used terms which are synonyms with classic Malay's thinking pattern which is "kiasan" or figurative language.

Why didn't Za'ba use the "rhetoric" term in the book? We assume that Za'ba might think the terms do not precisely substitute the figurative as there are differences in the characteristic of semantic field. The second possibility is that the rhetoric term is a negative connotation which opposes the figurative concept in Malay language that reflected positive meaning. Furthermore, rhetoric in modern meaning can be defined as word games or word usage that only influences the audience minds.

This negative connotation concludes that the rhetoric term is not suitable to substitute figurative term that reflects positive meanings in Malay speaking art. But, as rhetoric term has been assimilated with balaghah entry in most of dual language dictionary, and at the same time Malay language scholars have yet to find new word which carry the true meaning of balaghah, therefore the usage word "rhetoric" which is borrowed from English is still needed till today. In one word, Malay rhetoric knowledge discipline can be categorized into three categories as shown in Figure 1:

Figure 1. Malay rhetoric knowledge category based on Za'ba.

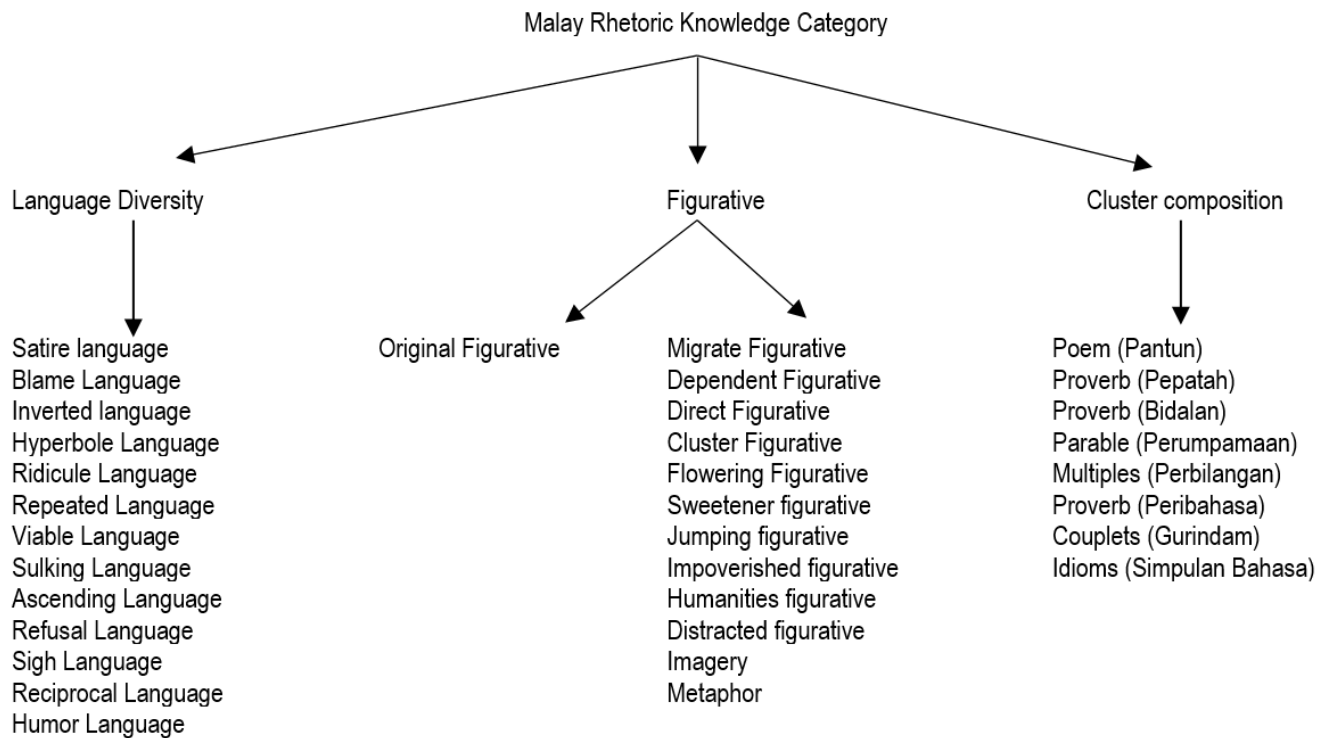


One of the reasons for the lack of interest on rhetoric among modern Malay linguistic scholars is because; Malay rhetoric characteristics was known in multiple names such as language style, proverb, metaphor, allusion language, fine language, figurative language, language beauty, courtesy language. Secondly, all of these characteristics are unarranged and in one established knowledge discipline. Third, the absence of specific name that represents the entire beauty concept in Malay language. Last but not least, Malay language is beautifully seen separately from classic rhetoric views, stylistic, semantic, semiotic, esthetic and poetic though these fields are only branches of bigger knowledge source, which is the Malay rhetoric knowledge. All of the issues and problems do not clearly explain the beauty concept in Malay language and in need of a complete and systematic knowledge mapping before the process of Malay rhetoric discipline can be a reality.

\section{Research Objective}

Describe issues around Malay figurative language and its potential to progress into a new discipline knowledge.

Discuss similarities between Malay allusion and majaz concept of the Arabic rhetoric.

\section{Scope and Research Limitation}

Majaz is one of ilm bayan in Arabic rhetoric. Besides, in Malay language it derives from term 'Bayan' that is mentioned in Kamus Dewan (2014) which means clear and obvious. However, ilm bayan is defined as a knowledge that explains the meaning of words in al-Quran (Noresah Baharom, et al. 2007, p 141). In Malay language, there is no long vocal as used in Arabic language, however, the term 'bayan' in Kamus Dewan does not encompass all aspects of ilm bayan as same as that has been discussed in Arabic language. The reason is ilm bayan has a vast and large scope of discussion which completes the aspect of tashbih (similarity based figures of speech in Arabic), isti'arah (metaphor proper), kinayah (symbolic similarity) and majaz (metaphor). Contrarily, in Arabic language, the direct meaning is called as a real meaning and figurative meaning or metaphor which is named as majazi. After identifying the scope of discussion of ilm bayan in Arabic language, we can say that the concept of ilmu bayan in Malay language is closer to figurative language. The researcher has used the written book named Jawahir Balaghah and its author is Ahmad al-Hashimi (2008) as main reference and source instead of the written book by Za'ba which is called IImu Mengarang Melayu (2002).

\section{The Similarity of Majaz in Malay Language and Arabic Language}

In Malay language, art of majaz or figurative language has several purposes such as: i) Caring others feeling and heart. ii) Preserve the tradition and ethic in communication especially whenever interacting with the elders such as parents, teachers, leaders, and religious scholars. iii) Ensuring that the used words while communicating is more suitable and beautiful, attractive and, warmly pleasant, easier to be understood, and affecting those who are listening to it.

There are two types of majaz in Arabic language: Figure of language (linguistic metaphor) or called metonymy (majaz mursal) and figure of reason and intellect called conceptual metaphor (majaz 'aqli) (Ahmad al-Hashimi, 2008). In spite of this, both majazs in Malay language according to Za'ba's classing are categorized to 'figuration or metaphor'. On the other hand, not all classifications in majaz mursal and majaz 'aqli which are discussed in Arabic rhetoric are available within Za'ba explanation. These both majazs are categorized by Za'ba (2002, p 197-207) to be in moving figuration (kiasan berpindah) which includes jumping figuration (kiasan melompat), humanizing figuration (kiasan permanusiaan), mix figuration (kiasan berkacau), assimilating, likening, representing, figurative comparison and figurative representation.

\section{Linguistic Metaphor (Figure of language)}

Metonymy (Majaz Mursal)

Metonymy means using any words which is not the real meaning of it. And there is a relation which is not seemed to be like tamshil (representing). Yet, there is a qarinah (circumstantial indicator) that shows it cannot be used for real meaning (Ahmad al-Hashimi, 2008 p 320). This majaz is included in majaz lughawi (linguistic metaphor) which refers to any words that do not indicate the real meaning. However, if there is an element of similarity (tashbih), it will be put in category of metaphor proper (isti'arah). 
In Malay language, the correct meaning for similarity or isti'arah is called "metafora". Meanwhile some examples of majaz mursal in Malay language is more closer to 'alusi' (allusion); indirect reference and 'personaifikasi' (personification); projection of character of humans. In accordance with types of metaphorical meaning (makna majazi) of relation (alaqah); alaqah is a relation that exists between its real or literal and the current metaphorical meaning; in a speech, a listener may be able to guess what was meant by a speaker with his speech. The related meaning that has been always seen is found in linguistic metaphor (majaz lughawi) or metonymy (majaz mursal) as shown in Table 1:

Table 1: Majaz with word classification.

Relation of being the part

Relation of being the whole

Relation of considering what will be

Relation of considering what was

Relation of being the cause
Relation of being the effect

Relation of being the one occupying the place

Relation of generality

Relation of being the place that is occupied

Relation of tool

\section{a. Relation of Being the Part (Alaqah Juziyyah)}

This type of majaz happens when it mentions whole aspect of something, but what was meant is only a part of it. For example in al-Quran, Allah says: "The fornicatress and the fornicator flog each of them (by giving) hundred stripes..." (anNur, verse 2). The meaning of flogging in this verse does not mean to flog or whip a whole body of the adulterer, but only flogs certain part of the body. So, in this verse, it seems to flog the body wholly. In spite of that, what was meant is only certain part of it. For example of this majaz in Malay language such as: "Budak-budak itu minum air Sungai Kelang" (The boys drink the water from Kelang River). The meaning that was basically meant from this sentence does not comprise whole water, but on the contrary it means just a little bit of drank water of Kelang River. Another example of this majaz in commanding sentence: "Ali, pergi ikat kambing itu!." (Ali, tie the goat!). The literal meaning of this sentence seems to ask or command Ali to tie the whole body of the goat, but in fact, it actually means to tie only the part of its neck.

\section{b. Relation of Being the Whole (Alaqah Kulliyyah)}

Majaz of this relation happens when the relation is only mentioned partly, but the meaning of it needs the whole relation. For example in al-Quran, Allah says: "...and bow and down with those who bow down..." (al-Baqarah, verse 43). In this verse, the action of bow (rukuk) that was mentioned here is one of the pillars of prayer (solat). In contrast, the literal and real meaning of the verse is referred to whole pillar of the prayer. Nevertheless, the phrase "never aim at or never face toward" means never perform solat because the action of turning the whole body towards the direction (kiblat) which is located at Mecca is one of the pillars of prayer.

Another example from Malay language, such as: "Saya bercadang memberi sepatah dua kata dalam majlis itu" (I would like to deliver one or two words in that event). The meaning of this sentence is to deliver a speech that consists of many words, but the sentence only mentions 'one or two words' which is clearly in form of majazi or metaphorical. Likewise, this sentence in Malay language: "Sudah begitu lama kami tidak nampak batang hidung Ahmad" (It has been quite a while since we last saw Ahmad's nose). The actual meaning of this sentence is not referred to the sense of Ahmad's nose; however it refers to the whole body of him.

\section{c. Relation of Considering What Will Be (Alaqah Iktibar Ma Yakun)}

This type of majaz is formed when something was mentioned does not exist yet. However, it was expected to exist later on. For example in al-Quran as Allah says: "So if he divorces her (after second divorce), she shall not be lawful to him afterwards until she marries another husband..." (al-Baqarah, verse 230). The meaning of another husband that has been stated in this verse means a man who is married with a woman. The use of word 'husband' shows anything that will happen after getting married which makes the woman legally married with a husband.

In Malay language, Za'ba named this type of majaz as a jumping figuration. For example: "Dia sedang masak nasi" (He is cooking the rice). The word 'rice' that has been mentioned basically still not exist yet. It is because the thing that had been 
cooked was rice grain, however the rice are expected to be exist after completing the process of cooking the rice grain is done. Another example is like the phrase "menoreh getah" (rubber tapping). It actually means tapping a trunk of rubber tree purposely to get its latex.

Besides, the phrase "menjahit baju" (sewing dress). Logically it means to sew some fabrics in order to produce a dress. Another example is like the phrase "menggali perigi" (digging a well). It actually means to dig a land to make a well. Furthermore the phrase "membakar lemang" (burning lemang/bamboo rice). It definitely means to burn bamboos with fire which are fully stuffed with rice to make lemang (bamboo rice). Then the phrase "membalut ketupat" (wrapping ketupat). It means to wrap or weave leaves of 'palas' with glutinous rice to be 'ketupat'. And lastly the phrase "memanjat langsat" (climbing langsat). It clearly means to climb the tree to get langsat fruit.

\section{d. Relation of Considering What Was (Alaqah Iktibar Ma Kana)}

This type of majaz (metaphor) occurs when something that has been mentioned is something that shows about what has happened. For example from al-Quran, Allah says: "Whoever comes to his Lord (being) guilty for his is surely hell; he shall not die there in, nor shall he live..." (Ta Ha, verse 74). In this verse, the term 'guilty' is a character of someone who was involved when he or she was in earth during the living time whereby in the Day of Judgement no one can do guilt and sins anymore. Therefore, the word 'guilt' in that verse is purposely used because it is to refer to the guilt that had been committed when the guilty one was still in the earth. In Malay language, for example someone who is an adult calls somebody who had ever taught him a long time ago whenever he was at school by calling him or her as a 'cikgu/teacher'. On the other hand, even though the teacher is already retired for such a certain period of time, he or she is still called as a 'teacher' in which refers to his previous title a long time ago.

\section{e. Relation of Being the Cause (Alaqah Sababiyyah)}

The relation of being the cause or sabbabiyyah is formed when a mentioned phrase indicates to a cause or a factor of something without giving any effect or result of it. For example in al-Quran, Allah says: "And the recompense of evil is an evil like thereof..." (ash-Syura, verse 40). Here, the phrase 'an evil like thereof' means punishment that has been charged although the word 'evil' is mentioned as a punishment for evil action which was conducted and becomes a cause of the punishment. For example in Malay language: "Mereka menjamu selera di restoran Nasi Kandar" (They are eating taste at Nasi Kandar restaurant). Originally, it means they are eating foods not tasting it. The reason is the taste only becomes a cause for making someone to eat. Thereby, the used word 'selera' or 'taste' in this sentence is being in the form of alaqah sababiyyah (relation of being the cause).

\section{f. Relation of Being the Effect (Alaqah Musabbabiyyah)}

This majaz happened when the mentioned phrase becomes an effect or a result that come out from any causes or factors. For example in al-Quran, Allah says: "And He who sends down sustenance from the sky..." (al-Mu'minun, verse 18). At first, the thing that was sent down from sky is rain. Meanwhile, the 'sustenance' or 'rezeki' in the verse means the effect of the falling rain from the sky. In another word, the rain is a factor that causes the growth of the trees which become sources and supplies of foods for all human beings in earth. The growth of these trees is the result or effect of the falling rain.

\section{g. Relation of Being the One Occupying the Place (Alaqah Haliyyah)}

This majaz is formed when a word that at first is used to refer to certain thing only, but after some changes of moving times the word was affected and become big and extended within its meaning until it encompasses another thing that has been in same category. For example in al-Quran, Allah says: "O Prophet, be careful of Allah and do not comply with (the wishes of the unbelievers and the hypocrites!" (al-Ahzab, verse 1). Even though the command in this verse is actually pointed to Prophet Muhammad PBUH, however the real meaning of it generally points to whole ummah of Islam.

Meanwhile, the example in Malay language is when someone says: "Saya mahu membeli pampers untuk anak saya" (I want to buy pampers for my baby). Actually what was meant with 'pampers' in the sentence is not the branded-baby diaper which is called 'Pampers', but it means all types of baby diapers generally. The word 'pampers' is usually taken because the brand is vastly used and very famous among Malaysians. Similarly, the word 'tupperware' is originally a name of a 
branded container that has been created from plastic to keep food and drink. Eventually it becomes popular in Malaysia until all food containers that are made from plastic are called 'tupperware'.

\section{h. Relation of Generality (Alaqah Umumiyyah)}

This majaz occurs when something is mentioned, it is in general form, but what was meant from it is a specific form. For example in al-Quran Allah says: "or do they envy the people for what Allah has given them of His grace?" (an-Nisa', verse 54). The word 'people' that has been stated in this verse shows the general form, but what it really needs is a specific one which referred to Prophet Muhammad PBUH.

\section{i. Relation of Being the Place that is Occupied (Alaqah Mahalliyyah/Makaniyyah)}

It happens whenever there is a connection between a meaning and a place, a location or a premise either in small scale or big scale. For example in al-Quran Allah says: "And ask the town in which we have been" (Yusuf, verse 82). The word 'town' in this verse refers to a place and it relates to its citizen. So, the word actually refers to 'citizen' in that town.

The same concept appears in Malay language such as "cukur kepala" (shaving head). What was meant by the phrase is shaving hair on a head is not totally to shave whole part of head. Besides, same thing happens to all these phrases, for examples: i) Lengan baju (sleeve) which means a part of dress that covers the area of arm. ii) Kaki seluar (pants leg) which means a part of pants that cover and hide the legs area. iii) Kepala paip (pipe head) which means a part of water pipe where the water comes out.

\section{j. Relation of Tool (Alaqah Aliyah)}

This majaz occurs when there is a connection between a meaning and a tool. For example in al-Quran, Allah says: "Then bring him before the eyes of the people..."(al-Anbiya', verse 61). This verse tells us about the story of Prophet Ibrahim who was brought to people to be investigated regarding to who has destroyed the idols of his people. The word 'eyes' was mentioned here because it is a sense of seeing for those who witness the session of the investigation. Similarly, in Malay language, for example: "daripada buaian hingga ke liang lahad" (from cradle to grave). The phrase means from birth till death. A cradle that becomes a place for a baby to sleep is a symbol of childhood, meanwhile the grave that becomes a place to bury and lay rest the dead body is a symbol of death. Likewise, in some phrases in Malay language, such as: "baju hujan" (rain dress), "lidah pendita" (priest tounge), "kalam lebih tajam daripada mata pedang" (words are sharper than edge of sword) and "bercebok" (washing hands and feet by using a vessel called "cebok"). If we look through Malay conversation, we will absolutely recognize that there are so many related meanings in which all the used words are indirectly from type of this majaz.

\section{Feature Similarities and Differences}

This discussion explains that if the concept of Arab rhetoric is used as a basis for examining the figurative language of the Malay, many interesting figurative language will be highlighted and probably never been thought by the researchers of the Malay language. These shapes can actually be expanded to explore all the treasures of the language, literature and Malay culture that are included in the dialects in the country. There are many similarities of the figurative art in Malay and Arabic language. It is concluded that the concept of Malay rhetoric is closer to the rhetoric in Arab's culture, compared to the rhetorical concept in Western culture. It turned out that the concept of transferring the Western rhetoric art (especially in language and literature) into Malay language and applied in the Malay language education curriculum should be reviewed.

This is because after decades, this approach fails to empower the Malay art of rhetoric, in reality it shows that it has been marginalized in the mainstream education, either at school or at public universities in Malaysia. We recognize the advantages of the figurative in Arabic as it is pinned by strong fundamentals, namely, al-Quran and al-Hadith, or even a debate about it has started since the second century of Hijra. However, this should not be an impediment to the researchers because of the lack of this can be addressed by adapting and modifying the art of language in the Malay archipelago and the Malay World like the art of speaking diasporic Malay language in Saudi Arabia, South Africa, Thailand, Singapore, Brunei, Indonesia, Cambodia, Sri Lanka, New Zealand and Australia. Malay rhetoric art actually have not been studied thoroughly and holistically, but still partly hidden in various genres of language, literature and culture. 
Featured arts equation rhetoric Arabic to Malay/Indonesia is also evidenced in the study of Yayan Nurbayan (2010) from Indonesia related to the science of al Bayan, one of the branches of Arab Rhetoric. In the study, Yayan proves that there are many similarities with Malay/ Indonesian, i.e. tashbih mursal, tashbih muakkad, tashbih mufassal, tashbih mujmal, tamsili, tashbih baligh, tashbih dhimni, majaz isti'arah tasrihiyyah, majaz mursal with variation, the relation, majaz aqli, kinayah sifat and kinayah nisbah. Aspects of the science of al-Bayan which differ in Malay/Indonesian is tashbih maqlub, majaz isti'arah makniyyah, isti'arah asliyyah, isti'arah tabaiyyah, isti'arah murashshahah, isti'arah mujarrodah, isti'arah muthlaqah and kinayah mausuf.

Review by Yayan Nurbayan (2010) solidifying this author's view that efforts to uplift the status of the Malay rhetoric should return to the tradition of the Malay civilization which is superior, namely Islamic scholarship, which language and Arabic literature will be always taken into account. Malay rhetoric gives the importance of new innovations from concept, design and theory by emphasizing the values of Arab-Islamic tradition of the science of rhetoric, as has been raised by the German scholar, Arndt Graf (2008, p xvii) by saying that one of the important aspects is the question of the original concept or theory in the Malay rhetoric. The concept of rhetoric is drawn from the European tradition, including the concept of poetic, stylistic concept and others. Through his Rhetorical Malay Annotated Bibliography published by DBP (Malaysia) in 2008, Graf hopes its various branches collect bibliographic Malay rhetoric article which can help one to find more information in the question of how the Arab tradition as eloquence of the Malay rhetorical sense very influential in Malaya. The mindset of the Malays with the Arab tradition clearly reflected from the similarity of their expressions that is often attributed to the nature, flora and fauna. Thinking patterns like this is in accordance with Islamic religion and culture that they embrace that which in the Quran is so rich with symbols and metaphors which aims to enable people to read, to think, to understand and appreciate the various metaphors and symbolic expression.

\section{Conclusion}

The effort to empower the science of Malay rhetoric which includes the figurative aspects should be intensified because this knowledge can link between linguistic discipline with Malay literature in the context of Malaysian education which is often seen in separate ways and to some extent it generates differences in concept, philosophy and objectives of learning those fields. Another contributing issue to this confusion is the weakness in terms of the education that focuses of the importance of learning grammar and rhetoric language. Emphasizing on grammar education can breach the beauty of language arts education, while learning the intricacies of grammar and learn to use the language with good and beautiful language is two different things.

This phenomenon leads to the birth of Malay graduates who are too concerned with grammar accuracy than the aesthetic aspects of the language. Grammar can only be measured by the correct sentence on the basis of external meaning. It cannot be used for the paragraph that is allegorical, but not the grammatical knowledge. The generation of the new knowledge can measure the characteristics of the beauty of the Malay language clearly and systematically. Strictly speaking, the disciplinary of the Malay rhetoric science can clarify the focus on the education of the Malay language and literature, which gives the images and new innovation as well as reducing friction about the direction of the two fields.

\section{References}

Abdullah Yusuf Ali. (2008). The Holy Quran with English Translation \& Selected Commentaries. Kuala Lumpur: Saba Islamic Media Sdn Bhd.

Abdullah b. Mohamad (Nakola).(1980). Falsafah dan Pemikiran Orang-orang Melayu. Hubungannya dengan Islam dan Kesenian, Kuala Lumpur: Kementerian Kebudayaan, Belia dan Sukan Malaysia.

Abdul Kadir Husain. (1977). Fan al-Balagha. Cairo: Muassasah al-Risalah.

Abdul Wahid Salleh. (2006). IImu al-Ma'ani. Kuala Terangganu: Bayt al-Hikmah.

Ahmad al-Hashimi. (2008). Jawahir al-Balagha. Beirut: Muassasah al-Ma'arif.

Arndt Graf. (2002). Bibliografi Retorik Melayu Beranotasi. Kuala Lumpur: Dewan Bahasa dan Pustaka. 
Asmah Haji Omar (2014). Za'ba: Ahli Fikir dan Ahli bahasa. Kuala Lumpur: Dewan Bahasa dan Pustaka.

Balkis Hj Abu Bakar et al. (1999). Prosiding Seminar Balaghah (Retorika) Arab - Melayu, Jabatan Pengajian Arab dan Tamadun Islam, Fakulti Pengajian Islam, Universiti Kebangsaan Malaysia.

Glosari Bahasa dan Kesusasteraan Arab. (2002). Kuala Lumpur: Dewan Bahasa dan Pustaka.

Noresah Baharom et al.(2007). Kamus Dewan. Fourth Edition. Kuala Lumpur: Dewan Bahasa dan Pustaka.

Raja Ali Haji.(2005a). Bustanul al-Katibin. Kuala Lumpur: Yayasan Karyawan.

Raja Ali Haji.(2005b). Kitab Pengetahuan Bahasa. Kuala Lumpur: Yayasan Karyawan.

U.U. Hamedy.(1988). Kesusasteraan Islam di Rantau Kuantan. Riau: Payung Sekaki.

Yayan Nurbayan. (2010). Pengembangan Materi Ajar Balaghah Berbasis Pendekatan Kontrastif. Jurnal Bahasa dan Seni, Tahun 38, Nomor 1, Februari. http://sastra.um.ac.id/wp-content/uploads/2012/01/11.-Yayan.docx.pdf.

Za'ba. (1934). Ilmu Mengarang Melayu. Edisi Jawi. Kuala Lumpur: Dewan Bahasa dan Pustaka, Kementerian Pelajaran Persekutuan Tanah Melayu.

Za'ba. (2002). Ilmu Mengarang Melayu. Edisi Rumi. Kuala Lumpur: Dewan Bahasa dan Pustaka. 